\title{
Zymomonas mobilis squalene-hopene cyclase gene (shc): cloning, DNA sequence analysis, and expression in Escherichia coli
}

\author{
Ina G. Reipen, ${ }^{1}$ Karl Poralla, ${ }^{2}$ Hermann Sahm ${ }^{1}$ and Georg A. Sprenger ${ }^{1}$
}

Author for correspondence: Georg A. Sprenger. Tel: +492461 616205. Fax: +492461612710.

\footnotetext{
1 Institut für Biotechnologie 1 des Forschungszentrums Jülich $\mathrm{GmbH}$, PO Box 1913, D-52425 Jülich, Germany

2 Institut für Botanik, Mikrobiologie, Universität Tübingen, Auf der Morgenstelle 1, D-72076 Tübingen, Germany
}

\begin{abstract}
Using a DNA probe from the gene encoding squalene-hopene cyclase (SHC, EC 5.4.99.-) from the Gram-positive bacterium Alicyclobacillus acidocaldarius, we have cloned a $4 \cdot 3 \mathrm{~kb}$ Hindill fragment of chromosomal DNA from Zymomonas mobilis. An open reading frame of 1977 bp was detected that could encode a protein of 658 amino acids with a calculated molecular mass of $74077 \mathrm{Da}$. Under the control of lac or tac promoters, this gene, shc, was expressed in Escherichia coli K12 strains and its product had squalene-hopene cyclase activity. Sequence alignments with the $A$. acidocaldarius SHC, the lanosterol cyclase of the yeast Candida albicans, and the cycloartenol synthase of the plant Arabidopsis thaliana revealed six highly conserved regions (mainly in the C-terminal part) of the proteins. These regions contained the core motif Gln-XX-X-Gly-X-Trp.
\end{abstract}

Keywords: hopanoids, squalene, squalene-hopene cyclase, lanosterol cyclase, Zymomonas mobilis

\section{INTRODUCTION}

In contrast to eukaryotes, bacteria do not produce sterols as membrane constituents. Instead, some eubacteria (and protozoa) contain pentacyclic triterpenes of the hopanoid class which are regarded as structural and functional equivalents of sterols in these organisms (Ourisson et al., 1984; Poralla \& Kannenberg, 1987; Sahm et al., 1993). The intermediate squalene is at the branch point of the biosynthetic pathways for sterols and hopanoids (Taylor, 1984). Squalene-hopene cyclase (SHC, EC 5.4.99.-) is the first specific enzyme of hopanoid biosynthesis. While the cyclization of squalene to diploptene (hop-22(29)-ene) proceeds without the involvement of molecular oxygen, sterols are formed by $\mathrm{O}_{2}$-dependent oxidation of squalene to epoxysqualene, followed by the cyclization catalysed by, for example, lanosterol cyclase in yeasts or cycloartenol synthase in plants (Abe et al., 1993).

SHC from the thermophilic and acidophilic bacterium Alicyclobacillus acidocaldarius (formerly Bacillus acidocaldarius) has been purified (Neumann \& Simon, 1986; Seckler \& Poralla, 1986; Ochs et al., 1990), and the gene

Abbreviation: SHC, squalene-hopene cyclase.

The EMBL/GenBank accession number for the nucleotide sequence reported in this paper is $X 80766$. cloned, sequenced and expressed in Escherichia coli (Ochs et al., 1992). The purified enzyme showed a molecular mass of $75 \mathrm{kDa}$ on SDS-PAGE. The DNA-derived amino acid sequence comprised 627 amino acids with a molecular mass of $69 \cdot 5 \mathrm{kDa}$. The Gram-negative, ethanol-producing bacterium Zymomonas mobilis also contains a variety of hopanoids with different polar side chains which are thought to be involved in ethanol tolerance (Bringer et al., 1985; Ingram, 1986; Horbach et al., 1991). The membrane fraction contains up to $30 \mathrm{mg}$ hopanoids ( $\mathrm{g}$ dry weight $)^{-1}$, making $Z$. mobilis a rich source of biohopanoids (Hermans et al., 1991). This content is high in comparison to other bacteria, and it is independent of ethanol concentration and temperature (Schulenberg-Schell et al., 1989; Sahm et al., 1993). We undertook to clone and analyse the gene for SHC from $Z$. mobilis using a DNA probe from the Grampositive bacterium $A$. acidocaldarius.

\section{METHODS}

Bacterial strains, plasmids and culture conditions. Zymomonas mobilis strain CP4 (ATCC 31821) (Goncalves de Lima et al., 1970 ) was used. For cloning, the Escherichia coli K12 mutants DH5 (Low, 1968) and NM522 (Gough \& Murray, 1983) were used. Plasmids used were pUC18 and pUC19 (Vieira \& Messing, 1982), pGEM-7-Zf(+) (Promega), pUCBM20 (Boehringer Mannheim), and pZY507 (lac $I^{\mathrm{q}}$, tac $P$, cat $)$, a mobilizable plasmid constructed by our group (G. A. Sprenger, S. Schilz \& H. Sahm, unpublished results). Plasmids pZY601 and pZY602 
contain a $2.9 \mathrm{~kb}$ DraI fragment including the $Z$. mobilis shc gene, ligated into vector pUC19 ( $\mathrm{SmaI}$-digested) representing both orientations. Plasmid pZY603 contains a $4.3 \mathrm{~kb}$ HindIII fragment covering the $2.9 \mathrm{~kb} \mathrm{DraI}$ fragment completely in vector pZY507. In plasmid pZY603 the $s h c$ gene is inserted in appropriate orientation to the tac promoter. Plasmid pP2 contains the cloned $s h c$ gene from $A$. acidocaldarius DSM 406 (ATCC 27009) (Ochs et al., 1992) and was used to prepare the DNA probe. $Z$. mobilis CP4 and its derivatives were grown anaerobically in complex medium (VM) with $2 \%(\mathrm{w} / \mathrm{v})$ glucose (Uhlenbusch et al., 1991) using glass tubes (Bellco) stoppered with butyl rubber. Agar plates were incubated in jars (Oxoid) with a gas-generating kit to provide an anaerobic $\left(\mathrm{H}_{2} / \mathrm{CO}_{2}\right)$ environment. $E$. coli strains were grown in LB medium (Sambrook et al., 1989) with appropriate antibiotics. Plasmids pZY507 and pZY603 were transferred by conjugation from $E$. coli donors to $Z$. mobilis $\mathrm{CP} 4$ as described previously (Uhlenbusch et al., 1991).

Oligonucleotide preparation, labelling and DNA hybridization. DNA oligonucleotides were synthesized using a Gene Assembler (Pharmacia). The oligomers used to amplify the DNA fragment from $A$. acidocaldarius consisted of a 20-mer (TCCGCGCCTTGGACTGGTTG) and a 19-mer (GTGCCGAAACACTCGAGCA). Oligonucleotides were purified by passage through NAP 10 columns (Pharmacia). For Taq DNA polymerase-dependent cyclic DNA amplification (Mullis \& Faloona, 1987), oligonucleotides were used as primers (50-100 ng each) and an internal fragment of the cloned $A$. acidocaldarius gene was used as the template (100 ng). DNA amplification was done in $50 \mathrm{mM} \mathrm{KCl}, 1.5 \mathrm{mM} \mathrm{MgCl}_{2}, 10 \mathrm{mM}$ Tris/ $\mathrm{HCl}, 0.1 \mathrm{mg}$ gelatin $\mathrm{ml}^{-1}, \mathrm{pH} 8.3\left(20^{\circ} \mathrm{C}\right)$ with Taq DNA polymerase (Boehringer Mannheim) for 30 cycles of $94^{\circ} \mathrm{C}$ $(1.2 \mathrm{~min}), 45^{\circ} \mathrm{C}(1.2 \mathrm{~min}), 70^{\circ} \mathrm{C}(2.2 \mathrm{~min})$. The amplified fragment was $643 \mathrm{bp}$ long (bp 987 to 1629 of the published sequence) (Ochs et al., 1992), and was labelled using random hexamer primers in conjunction with the digoxigenin-dUTP labelling kit of Boehringer Mannheim according to the manufacturer's instructions. The labelled fragment was used without further purification. $Z$. mobilis CP4 chromosomal DNA was cleaved with restriction endonucleases and $5 \mu \mathrm{g}$ samples were electrophoresed $(0.8 \%$ agarose $)$ in Tris/borate/EDTA buffer ( $\mathrm{pH} 8$ ). Afterwards, DNA fragments were denatured and neutralized (but not depurinated) and Southern blotted (Southern, 1975) to positively charged nylon membranes (Boehringer Mannheim) overnight in $10 \times$ SSC buffer. Prehybridization and hybridization were performed as described previously (Kessler et al., 1990). Hybridization temperatures and formamide concentrations were varied in the range $35-42{ }^{\circ} \mathrm{C}$ and $30-40 \%(\mathrm{v} / \mathrm{v})$, respectively. The filters were washed once with $0.5 \times$ SSC buffer and then with $0.1 \times$ SSC (both containing $0.1 \%$ SDS) at the hybridization temperatures. Detection was by light emission with AMPPD (3-(2'spiroadamantane)-4-methoxy-4-( $3^{\prime \prime}$ - phosphoryloxy) - phenyl1,2-dioxetane) as substrate for alkaline phosphatase, on a Kodak $\mathrm{X}$-ray film (type X-OMAT AR; 20-60 min exposure).

Cloning, restriction analysis, and DNA transformation. Chromosomal DNA from $Z$. mobilis was prepared by the lysozyme/freeze-thaw method (Eddy et al., 1988). Plasmid DNA was prepared by alkaline lysis (Sambrook et al., 1989) or via column purification (Diagen). DNA fragments were recovered by excision from agarose gels in Tris $(40 \mathrm{mM}) /$ acetate $(20 \mathrm{mM})$ buffer at $\mathrm{pH} 8$, and were purified using glassmilk/ iodine (GeneClean kit, Dianova). DNA fragments were ligated with T4 DNA ligase (Boehringer Mannheim) with vector pUC19 (Vieira \& Messing, 1982), which had been cleaved with restriction enzymes and dephosphorylated. The ligation mixture was used to transform $E$. coli strain NM522. Transformants were selected on LB agar plates containing ampicillin $\left(100 \mathrm{mg} \mathrm{l}^{-1}\right)$ and $\mathrm{X}-\mathrm{Gal}\left(30 \mathrm{mg} \mathrm{l}^{-1}\right)$. DNA from 84 pools of 10 transformants each was prepared and analysed. The presumed DNA inserts were recovered by digestion with EcoRI plus HindIII, gel electrophoresed and Southern blotted (see above). From pools which gave positive signals in the hybridization assay, individual clones were re-analysed by digestion and hybridization.

DNA sequencing. DNA fragments were subcloned into vectors pUC18/19 or pUCBM20 for sequencing. Exonuclease III treatment (Henikoff, 1984) to create successively shortened clones was performed according to the protocols of the Erasea-base kit (Promega). The HindIII DNA fragment, containing the presumed $s b c$ gene, was sequenced by the dideoxy method (Sanger et al., 1977), using T7 DNA polymerase (Tabor \& Richardson, 1987) and the AutoRead sequencing kit (Pharmacia). Fluorescent-labelled primers (M13 universal and reverse-sequencing primers) were used as specified by the protocols for automated laser fluorescent (ALF) sequencing (Pharmacia). DNA was prepared by alkaline lysis and additionally treated with lithium chloride/2-propanol to remove RNA (Sambrook et al., 1989). Each sequencing reaction used $5 \mu \mathrm{g}$ plasmid DNA. Both strands were sequenced using the ALF sequencer and the manufacturer's software. The sequence data obtained were further analysed using the MicroGenie program 7.0 (Queen \& Korn, 1984).

SHC assay. Cells of $Z$. mobilis from a $200 \mathrm{ml}$ culture were harvested in the late-exponential growth phase $\left(\mathrm{OD}_{600} 2\right)$; cells of E. coli (100 ml culture) were harvested at an $\mathrm{OD}_{600}$ of 1.5 . After centrifugation, the cells were washed with potassium phosphate buffer $(50 \mathrm{mM}, \mathrm{pH} 7 \cdot 5$, sparged with argon to remove oxygen; plus $14 \mathrm{mM}$ mercaptoethanol). After resuspension in $1 \mathrm{ml}$ phosphate buffer, cells were packed into a precooled $\left(-20^{\circ} \mathrm{C}\right) \mathrm{X}$-press chamber (type X-5; Bachofer) and kept overnight at $-20^{\circ} \mathrm{C}$. The cell paste was ruptured using an $\mathrm{X}$-press (Enerpac RD2510) by two strokes from each side of the chamber. The frozen cell paste was thawed and treated with DNase I to reduce viscosity. Protein was determined by a dyebinding method (Bradford, 1976) with BSA as a standard.

SHC activity was determined according to the method of Ochs et al. (1990) with modifications (Tappe, 1993). In a total volume of $250 \mu \mathrm{l}$, about $200 \mathrm{nCi}\left[{ }^{3} \mathrm{H}\right]$ squalene $[50 \mu \mathrm{M}$; sp act. $16.2 \mathrm{Ci} \mathrm{mmol}^{-1}\left(6 \times 10^{11} \mathrm{~Bq} \mathrm{mmol}^{-1}\right), 4.4 \times 10^{5}$ d.p.m. per assay] was incubated at $30^{\circ} \mathrm{C}$ for 1 to $3 \mathrm{~h}$ with crude extract $\left(3 \mathrm{mg}\right.$ protein $\left.\mathrm{ml}^{-1}\right)$ in potassium phosphate buffer $(100 \mathrm{mM}$, $\mathrm{pH} 6.0)$ and $0.5 \%(\mathrm{w} / \mathrm{v})$ CHAPS [3-((3-cholamidopropyl)dimethylammonio)-1-propane-sulfonate]. The incubation was stopped by extraction with 2 vols hexane/2-propanol ( $3: 2$, $\mathrm{v} / \mathrm{v})$. The organic phase was applied to a thin-layer silica gel plate (Merck no 5715). The sample was air-dried and developed in a vertical tank, first with chloroform (to $7 \mathrm{~cm}$ ) then with hexane (to $16 \mathrm{~cm}$ ). The dried TLC plate was analysed in a TLC scanner (LB 2821; Berthold). Authentic, non-labelled standards of hopene (gift from Dr M. Rohmer, Université de Haute Alsace, Mulhouse, France) and squalene (Sigma) were visualized with iodine vapour. The isotope peaks were integrated and calculated to give the amount of hopene being formed.

Preparation of hopene for GC/MS analysis. $E$. coli DH5(pZY601) was grown under aerobic conditions at $30^{\circ} \mathrm{C}$ in 
Squalene-hopene cyclase from Zymomonas mobilis
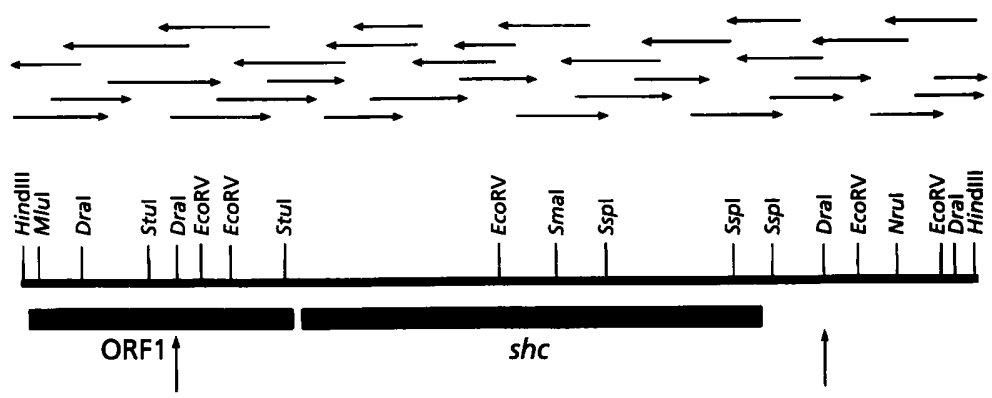

Fig. 1. Restriction map and sequencing strategy of the $4.3 \mathrm{~kb}$ HindIII DNA fragment containing the she gene of $Z$. mobilis. ORF1 designates the ORF upstream of shc. The two vertical arrows indicate the borders of the Dral fragment cloned on pZY601 and pZY602. The horizontal arrows indicate the orientation and length of sequenced fragments created by subcloning or by exonuclease III treatment.

eight $200 \mathrm{ml}$ volumes of $\mathrm{LB}$ with ampicillin to $\mathrm{OD}_{600} 1 \cdot 45$; $1 \mathrm{mM}$ IPTG was then added and growth was continued for $4 \mathrm{~h}$ to OD 1.75. The cells were washed, resuspended in $9 \mathrm{ml}$ $100 \mathrm{mM}$ potassium phosphate, $\mathrm{pH} 6.5,0.5 \%$ CHAPS. Squalene $(1 \mathrm{mg})$ in $1 \mathrm{ml}$ of the same buffer was sonicated and added to the suspension to stabilize the cyclase. This suspension was ruptured by $\mathrm{X}$-press treatment as above. Nine millilitres of $100 \mathrm{mM}$ potassium phosphate $\mathrm{pH} 6.5,20 \%$ (v/v) glycerol, $1 \%$ CHAPS plus an ultrasonicate of $10 \mathrm{mg}$ squalene in $1 \mathrm{ml}$ of the same buffer were added to the total cell homogenate. Incubation was for $4 \mathrm{~h}$ at $30^{\circ} \mathrm{C}$. The reaction mixture was extracted twice with $10 \mathrm{ml}$ hexane/2-propanol $(3: 2, \mathrm{v} / \mathrm{v})$ and centrifuged to increase phase separation. The extract was evaporated and purified by preparative TLC on silica gel (solvent system: to $6 \mathrm{~cm}$ with dichloromethane, and after drying, to $18 \mathrm{~cm}$ with hexane). The region with the same $R_{F}$ value as hopene was scraped out, extracted with dichloromethane and filtered. After evaporation the residue was redissolved and analysed by GC/MS, as follows. The gas-liquid chromatograph was a Carlo Erba Fractovap 2009 connected to a Varian mass spectrometer MAT $112 \mathrm{~S}$ (ionization $-80 \mathrm{eV})$. The column was a CP-Sil-5 $(10 \mathrm{~m} \times 0.25 \mathrm{~mm}$, film thickness $0 \cdot 12 \mu \mathrm{m}$ ) and was run at a temperature gradient of $5^{\circ} \mathrm{C}$ $\min ^{-1}$ from $220-300{ }^{\circ} \mathrm{C}$.

\section{RESULTS AND DISCUSSION}

\section{Detection of the shc gene with a heterologous DNA probe}

In order to clone the shc gene of Z. mobilis, we prepared a DNA probe from the gene of the Gram-positive bacterium $A$. acidocaldarius. The gene was cloned and sequenced recently (Ochs et al., 1992). From plasmid pP2, an internal $643 \mathrm{bp} \mathrm{XboI} \mathrm{fragment} \mathrm{was} \mathrm{amplified} \mathrm{using} \mathrm{Taq}$ DNA polymerase and two oligonucleotide primers, and was digoxigenin-labelled to produce a non-radioactive probe for $s b c$. Chromosomal DNA from Z. mobilis was prepared and digested in parallel with different restriction enzymes. The digests were agarose gel electrophoresed and blotted onto nylon membranes, and further processed for DNA hybridization with the digoxigenin-labelled DNA probe. Positive signals could be best visualized under low-stringency conditions : $30 \%(\mathrm{v} / \mathrm{v})$ formamide at $40{ }^{\circ} \mathrm{C}$. Hybridization signals were found with DNA digested with HindIII in the range of $4.3 \mathrm{~kb}$, and with DraI in the range of $3.0 \mathrm{~kb}$. To clone the respective DNA fragments, appropriately digested DNA (size range 3.5$4.5 \mathrm{~kb}$ for HindIII, or $2 \cdot 8-3.3 \mathrm{~kb}$ for $D r a \mathrm{I}$ was recovered from agarose gels and ligated to pUC19 vectors cleaved with HindIII and SmaI, respectively.

\section{Cloning and nucleotide sequence determination}

Of $840 \mathrm{HindIII-derived} \mathrm{clones,} \mathrm{two} \mathrm{contained} \mathrm{an} \mathrm{insert} \mathrm{of}$ $4.3 \mathrm{~kb}$ (plasmids pZY611 and pZY612 representing both orientations, data not shown). By restriction analysis, we found that a $2.9 \mathrm{~kb}$ DraI fragment which had also given a positive hybridization signal (data not shown) was present completely in the $4.3 \mathrm{~kb}$ HindIII fragment. The sequence of the $4.3 \mathrm{~kb}$ HindIII fragment was determined from both strands. The sequencing strategy and the derived restriction map are given in Fig. 1. Sequence analysis revealed that an open reading frame (ORF) of $1977 \mathrm{bp}$ was present on the DraI subfragment (Fig. 1). The complete sequence of the $4.3 \mathrm{~kb}$ HindIII DNA fragment with the delineated amino acid sequences is given in Fig. 2. Five base pairs upstream of putative start codon for the $s h c$ ORF there was a canonical Shine-Dalgarno sequence (Gold et al., 1981). A possible stem-loop structure with a $\Delta G^{0^{\prime}}$ of $-32 \mathrm{kcal} \mathrm{mol}^{-1}\left(-134 \mathrm{~kJ} \mathrm{~mol}^{-1}\right.$ ) (Tinoco et al., 1973) could form immediately after the stop codon and resembles a rho-independent terminator. Upstream of the putative $s h c$ gene, another ORF (ORF1) was detected that ends just 2 bp ahead of the RBS from $s h c$. The nature of this ORF is unclear. A databank search (data not shown) revealed that ORF1 shares stretches of amino acid residues identical to conserved sequences in phytoene desaturase enzymes of bacterial or plant origin (Armstrong et al., 1993).

However, this peculiar organization hints at a putative operon structure (unpublished results) and should allow read-through from a given external promoter into the putative $s h c$ sequence. The $1977 \mathrm{bp} s h c$ ORF could encode a protein of 658 amino acids with a calculated molecular mass of $74077 \mathrm{Da}$. The amino acid composition is apparently hydrophobic, as was found for the SHC from $A$. acidocaldarius (Ochs et al., 1992). An alignment of the SHC sequences from $Z$. mobilis and $A$. acidocaldarius with the oxidosqualene (lanosterol) cyclase from Candida albicans (Buntel \& Griffin, 1992; Roessner et al., 1993) and cycloartenol synthase of the plant Arabidopsis thaliana 


\begin{abstract}
ORFI AAGCTTGCCCTGTTATGGACTITGCTCAGATTGAGGGIGACTICATGAGTGTACGCATATTATCGGGG G L A G L S A A YA T TA G G YK I Y A GGGACTGGCTGGATTATCTGCCGCGGTAGCGATIACCCATGCTGGAGGACGCGTCAAAATTTATGAAGGCC 140 S A H A G R A R S Y H DKK L G I E I D N G TIGGCCATGGCTGGGGGACGGGCGCGITCCIAICATGATAAAAAGCTGGGGATTGAAATTGACAATGGCA 210
\end{abstract} H I L L S 6 H H S A K T Y L K A I 6 A E H R F atCATATGCIGCTGTCAGGCAATCATICTGCCAAGACCTATTTGAAAAGAATAGgGGCAGAGCATCGTTT 280

$K$ S P $K$ E A A F S F C D L S 0 K E R F T I $K L$ tAAAAGICCAAAAGAGGCCGCCITTTCTTTTTGTGAICIAAGCGACAAAGAACGCTTTACCATTAAGTTA 350

S $G P L P A W V L C A K S R V P \| S K A K D Y$ AGTAATGGCCCCTTACCTIGGIGGGTITTATGCGCCAAAAGCCGCGICCCICATAGCAAAGCCAAGGATT 420

L A L L S L L L A D N M T K I 6 O L Y P O N T AITTAGCGTTATTGTCGCTGTTATTGGCAGATCATAATACGAAAATAGgigACCTTGTTCCGGATAATAC 490

A L R L L L P F F Y S Y L T P A R G A GGCITIAIGGCGTAAATTGCTIGATCCTUIIUITGTATCGGTTCTCAATACACCGGCAAGAGAAGGGGCT 560 A C L A A A Y R E L LKG GKA C I P I A GCCTGTCTGGCGGCAGCGGTTATTCGGGAAACTITGATGAAAGGGGTAAGGCCIGTATCCCCCGTATCG 630

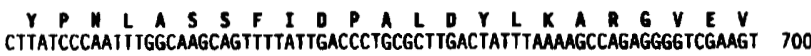
- f r m r l o i h f 5 g o d y a s l e f a h TGATITCCGTAACCGCCTCCGTCAAATCCATIIITAGGTCAGGATGTCGCCTCTCIGGAATITGCTCAT 770

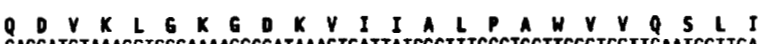
CAGGATGTAAAGCTGGGAAAGGGGATAAAGTGATTATCGCTITGCCTGCTTGGGTCGIICAAICCTTGA 840

P D I E T P DKY $P A$ I I NA H F L NK P T A TACCAGATATCGAAACGCCGGAIAAATATCAGGCGATTATCAACGCTCATTTCCTGATGAAGCCTACTGC 910 A M P I I G V V G G TA D WIFT F E I I GGCTATGCCTCATATTATGGGTGT TGTCGGAGGAACCGCTGATTGGATTTTCACTITTGAAAATCGGATA Y80

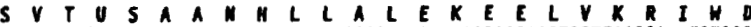
TCGGTTACGATCAGCGCCGCTAATCATIIAIIGGCGCTTGAAAAAGAAGAACTGGTTAAGCGTATCTGGG 1050

D I Q ATGATATTCAGACCGITTATGCTTTCAAACAGGATATGCCTAAATGGCAGGTCGTGACTGAGAAAAGAGC 1120 T F E A CACTITTGAAGCGACTGTCGAGCAGAATAAICGTCGCCCACCGGCGGTTACAGCGTGGAATAACCTGTTT 1190

L A G H H Y R T G L P A T I E S A I R S G O T A TTAGCCGGAAATTGGGTGAGAACAGGCCTGCC IGCGACTATTGAAAGCGCTATACGAICTGGCCAGACTG 1260

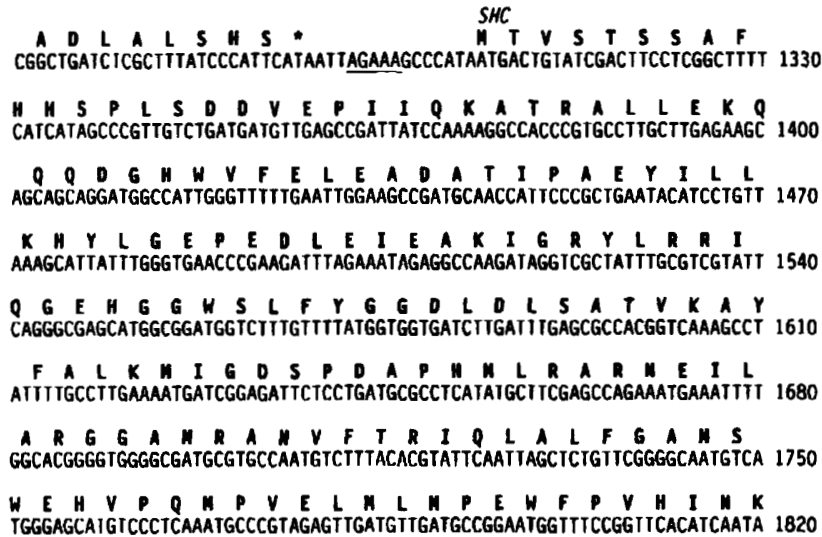

Fig. 2. Nucleotide sequence and derived amino acid sequence (single-letter code in bold face) of a 4347 bp DNA fragment (HindIII) containing the putative shc gene from $Z$. mobilis and an unknown ORF1. The putative ribosomebinding sites (RBS) are underlined, the stop codons are marked by asterisks and a possible stem-loop structure is marked by double lines $3^{\prime}$ to the shc sequence.

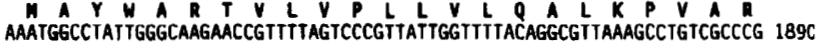
N R R G I L Y D E L F Y P D Y L P T L O E S $G$ TAATCGGCGCGGTATCTTGGTTGATGAATTAITTGTGCCGGATGITTTACCGACCCTICAGGAAAGCGGT 1960 D P I L R F F S A L D K V L N K V E P Y W P K GACCCTATATGGCGICGIUIIITTCGGCACTTGATAAGGTATTGCATAAAGTAGAACCTIAI IGGCCGA 2030

H I R A K A I I S C V H F V T E R L M G E O $G$ AAAATATGCGCGCGAAGGCIATICATAGCTGTGTCCATITTGTGACCGAGCGITTGAATGGTGAAGACGG 2100 L G A I Y P A I A S Y M Y D A L G Y P E M GITGGGIGCTATITAICCGGCGAIIGCCAATAGCGICATGATGTATGATGCCCTTGGGATATCCCGAAAAC 2170 M E R I A R Y E K L Y L D 6 T D O G CATCCAGAAAGAGCCATIGCCCGTCGGGCTGTCGAAAAATIGATGGTGTIAGATGGCACGGAAGATCAGG 2240

D K E Y C O P C L S P I D T L Y A A GTGATAAAGAAGTCTACTGTCAGCCTIGITIATCCCCGATTTGGGATACCGCITTGGTIGCCCATGCCAI 2310 L E Y G G O E A E K S A I S A L S W L K P O O GTTGGAAGTCGGAGGCGATGAGGCTGAAAAAICGGCTATTICTGCCTTGAGCTGGTTAAAGCCGCAACAA 2380

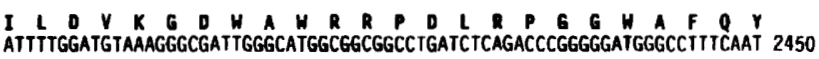

- N D Y Y P D V D D T A V V T M A M D R A A K ATAGAAATGACTATIATCCCGATGTCGATGATACGGCTGITGTGACTATGGCGATGGATCGAGCCGCAAA 2520

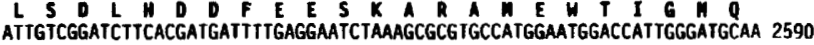
S D NGCGATAATGGCGGTTGGGGCGCTTTCGATGCCAATAACAGCIATACTTATCTGAATAATATTCCCTITG 2660 D I G A L L D P P T V D V S A R C V S H H A CTGATCATGGCGCGTIACTIGATCCGCCAACGGTCGATGTCTCGGCACGCTGCGTTTCAATGATGGCGCA 2730

A G $G$ I S S I I T GATGGTAGCIGGITCGGGCGTIGGGGTGTCAATTACATATATGGCACAIGGICGGCCTTATGTGCATTGA 2870

VA A L P ATGTGGCCGCITIACCCCATGATCATTTAGCTGTTCAGAAAGCTGTGGCIIGGCIGAAAACTATTCAAAA 2940 TCGACGGCTTCCCAAACAGCATGGGCTTTATTGGGCTTGATGGCTGTTGGGAAGCTAATICCGAGGCCG 3080 T K 6 I H L A O O O O E E 6 L W K E O Y Y Y S TGACAAAGGGTATAAACTGGTTGGCACAAAATCAGGATGAAGAAGGATIGIGGAAAGAAGATTATTATAG 3150 G G G F P R V F Y L R Y H G Y S K Y F P L TGGCGGTGGITITCCCCGIGITITITATCTTCGGTAICACGGTTATTCCAAATAIIITCCTCITTGGGCT 3220 $L A R$ Y R U L K K A M O P I Y TTAGCGCGCTATCGCAAITIGAAAAAAGCCAATCAGCCGATIGTICATTATGGGATGTAACAGGCTGATT 3290 TTATAACCIGITAGTAATGAAATACGTCTAAATCAAAATACGGCTGAITTTTTGGCCGTATTITITTGIA 3360 ITATCATATTGTTTITATAAAATATTGTGATGAITGGCGgGGTATTATGAAGGAAAAATATGCTGAACC 3430 ATATCCITGCTGTGACCGGAATAGAICGTGAAGCACGGGCGGCGGCGCAATGTGAAAAAGIUITGICTCT 3500 GGCAGGGGGAGGGGATAGTATICGTCTCGAAGAATCITIGCGCCGAATTATGCAAGAAAACACGATTGCC 3570 GGITTAGTGAGIIIIGGITTGGCTGGCGCITTGGATTCTGATTTAAAAGIAGGCGAITGGGTTGTCGGAA 3640 GCCATITAACAGGGAATGTCGATGCCGAI IGCGATGAAGCATGGCAAGACTCGCTIGAGAAAATIIICCC 3710 IAAATIAAAAAAGGGAATAATITATTCAGATGGCAGICITGIIICCGATATCGCCCAGAAACAAGACATT 3780 CAGAAAAAACAAAAGCTAICGCCGTIGATATGGAATCCCATATCGTTGCCCGAATAGCCCAAGAATATAA 3850 ITGTCCATTIATTATITTAAGAGTGATTTCAGA ICAGGCCGATCACGCTCTGCCTCCCGCITTTICGGTG 3920 GCGATGCAGCCTGATGGCAGCGTCGCGATACCAGCCCTAC TGAAATCATIGTTATTGAAACCGAGCCAAA 3990 TACCGGCTIICGTCACGACAGCAAAGGCCGCAACGAAAGCCTIGAAAGAGTTAGGCCGCGICGGIITCCT 4060 IITTGGCAGCAGCCTCGGCTTCCCGGATTTCGGCTAAACGCTGCTGAACGTGATCGGAGAACACGTCCTT 4130 GGCGCGACGCIGATIGGCAAGGCTGATATCGGGTGCCATAGCACCTTCIGIIITGATGCCTTTTAAAGCA 4200 ACCATAGCAGCTTICAACGGATGGCGAACCGTGTCGATAACCGCCGTGGCTICAAAACCAGAGIGAACCA 4270 IACAGTCTTGGCATITTICATAATIGCCAACGCCGTAATCATCCCAAGCCGTATITICCATAAGGTCTIT 4340
E D G G H G E W C D S Y Y A L D Y S S G Y E P 


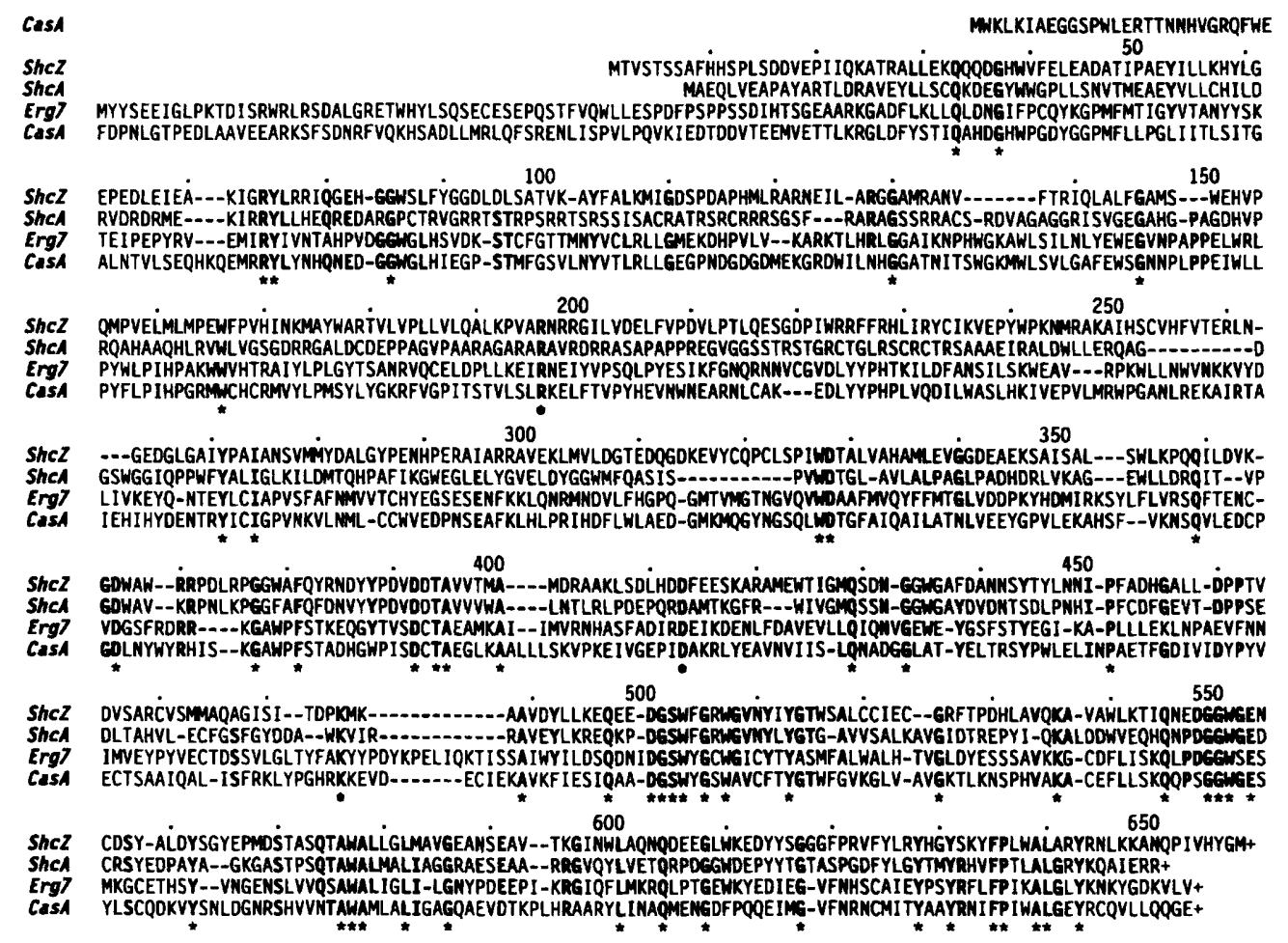

Fig. 3. Alignment of the derived amino acid sequences of SHC from Z. mobilis (ShCZ) with SHC from A. acidocaldarius (ShCA) (Ochs et al., 1992), lanosterol cyclase from Candida albicans (Erg7) (Buntel \& Griffin, 1992; Roessner et al., 1993) and cycloartenol synthase (CasA) from Arabidopsis thaliana (Corey et al., 1993). The alignment was done by the MicroGenie program 7.0 (Queen \& Korn, 1984) and fitted afterwards visually. Amino acid residues that are identical in at least three sequences are given in bold, and identical residues in all four proteins are additionally marked with an asterisk below the sequence. Residues are numbered according to the $Z$. mobilis sequence.

acidocaldarius (see Fig. 3). While a possible function of this motif in electron shift reactions during the cyclization of squalene to hopene (involving six electron pair shifts) is still speculative, it is nonetheless remarkable, especially as Trp residues are involved in several cation- $\pi$-electron interactions (Poralla et al., 1994).

\section{Expression of shc in Z. mobilis and E. coli K12}

That the presumed $s b c$ ORF indeed encoded a squalenehopene cyclase enzyme was shown by expressing the cloned DNA fragment in an E. coli host. E. coli DH5 with vector pZY507 and recombinant derivatives with the putative $s b c$ gene in the correct orientation to the tac promoter on plasmid pZY603 and to the lacZ promoter on plasmid $\mathrm{pZ} Y 601$, and in reverse orientation to the lac $Z$ promoter on plasmid $p Z Y 602$, were tested in a radioactive SHC $\left({ }^{3} \mathrm{H}\right.$-labelled squalene) assay. In parallel, extracts from Z. mobilis $\mathrm{CP} 4$ and its derivative $\mathrm{CP} 4(\mathrm{pZY} 603)$ were also assayed. Labelled products were detected by radioscanning TLC plates. As can be seen from Fig. 4, an additional peak that was more hydrophobic than squalene was only detected in recombinant $E$. coli strains containing the $s h c$ gene in the correct orientation to the lac $Z$ or $t a c$ promoter on plasmid pZY601 and pZY603, respectively.
Using unlabelled standards for squalene and hopene, this new peak was identified as hopene. It also appeared when cell extracts from $Z$. mobilis were incubated with squalene. This hopene peak was enlarged about five times with the recombinant $Z$. mobilis extracts (Fig. 4). A small, but visible, peak in the more hydrophilic region (possibly diplopterol) was also present in the TLC scans using $Z$. mobilis or recombinant E. coli extracts (see Fig. 4). Diplopterol is a known by-product of SHC activity in $A$. acidocaldarius (Seckler \& Poralla, 1986). We suggest that the 1977 bp ORF encodes squalene-hopene cyclase.

\section{Identification of hopene}

As a further proof of the expression of the gene for SHC of $Z$. mobilis in $E$. coli, the squalene conversion product of the recombinant $E$. coli strain DH5(pZY601), containing solely the putative $s h c$ gene in the correct orientation to the lac $Z$ promoter, was identified by GC/MS analysis. From a preparative enzyme assay of this strain, $1 \mathrm{mg}$ of a conversion product was isolated. Since E. coli does not produce squalene, a conversion product will not appear during growth. The isolated conversion product had the same properties in TLC, GC and MS as compared to hop21-ene (Rohmer et al., 1980). The most indicative fragments of the mass spectrum were: $410 \cdot 3\left(M^{+}, 21 \%\right), 367 \cdot 3$ $\left(M^{+}-\mathrm{C}_{3} \mathrm{H}_{6}, 9 \%\right), 341$ (below $5 \%$ ), 191.2 (ring C 


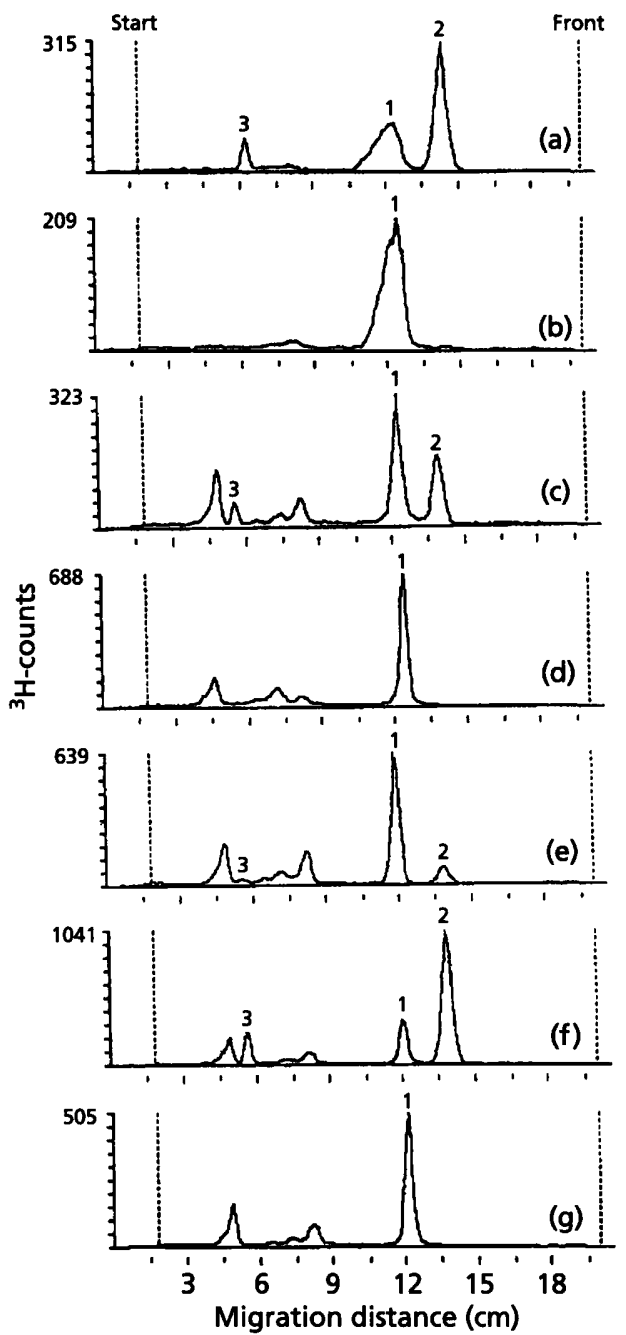

Fig. 4. Radioscans of thin-layer chromatograms showing conversion of $\left[{ }^{3} \mathrm{H}\right]$ squalene to $\left[{ }^{3} \mathrm{H}\right]$ hopene in cell-free $X$-press extracts from $E$. coli DH5(pZY601) (a), DH5(pZY602) (b), DH5(pZY603) (c), DH5(pZY507) (d), Z. mobilis CP4 (e) and CP4(pZY603) (f). A control incubation without cell-free extracts is given in $(\mathrm{g})$. The numbers above the prominent peaks are: 1 , squalene; 2, hopene; 3, diplopterol (putative). Other peaks were not identified. Total measuring time was $120 \mathrm{~min}$. Note the differences in the detectable counts, due to differing extraction efficiencies.

cleavage, $100 \%), 189 \cdot 2$ (ring C cleavage, $79 \%), m / z(\%)$. The molecular peak at $m / z 410 \cdot 3$ and the main fragment at $m / z 191 \cdot 2$ are very indicative of hopene. Therefore, it is evident that the expression of the $s b c$ gene was achieved and that the enzyme activity is caused by the sho gene product only.

\section{ACKNOWLEDGEMENTS}

We are indebted to Dr R. Welle, S. Horbach and T. Härtner for technical assistance and further advice. We thank $G$. Nicholson from the Institute of Chemistry at the University of Tübingen for GC/MS measurements, Dr M. Rohmer (Mulhouse, France) for the generous gift of hopene, and S. Peters for the photographs.

\section{REFERENCES}

Abe, I., Rohmer, M. \& Prestwich, G. D. (1993). Enzymatic cyclization of squalene and oxidosqualene to sterols and triterpenes. Chem Rev 93, 2189-2206.

Armstrong, G. A., Hundle, B. S. \& Hearst, J. E. (1993). Evolutionary conservation and structural similarities of carotenoid biosynthesis gene products from photosynthetic and nonphotosynthetic organisms. Methods Enqymol 214, 297-311.

Bradford, M. M. (1976). A rapid and sensitive method for the quantitation of microgram quantities of protein utilizing the principle of protein-dye binding. Anal Biochem 72, 248-254.

Bringer, S., Härtner, T., Poralla, K. \& Sahm, H. (1985). Influence of ethanol on the hopanoid content and the fatty acid pattern in batch and continuous cultures of Zymomonas mobilis. Arch Microbiol 140, 312-316.

Buntel, C. J. \& Griffin, J. H. (1992). Nucleotide and deduced amino acid sequences of the oxidosqualene cyclase from Candida albicans. $J$ Am Chem Soc 114, 9711-9713.

Corey, E. J., Matsuda, S. P. T. \& Bartel, B. (1993). Isolation of an Arabidopsis thaliana gene encoding cycloartenol synthase by functional expression in a yeast mutant lacking lanosterol synthase by the use of a chromatographic screen. Proc Natl Acad Sci USA 90, 11628-11632.

Eddy, C. K., Smith, O. H. \& Noel, K. D. (1988). Cosmid cloning of five Zymomonas trp genes by complementation of Escherichia coli and Pseudomonas putida trp mutants. J Bacteriol 170, 3158-3163.

Gold, L., Pribnow, D., Schneider, T., Shinedling, S., Singer, B. S. \& Stormo, G. (1981). Translation initiation in prokaryotes. Annu Rev Microbiol 45, 747-803.

Goncalves de Lima, O., De Araujo, J. M., Schumacher, I. F. \& Cavalcanti da Silva, E. (1970). Estudos de microorganismos antagonistas presentes nas bebidas fermentadas usadas pelo povo do Recife. I Sobre uma variedade de Zymomonas mobilis (Lindner) (1928). Rev Instit Antibiot Univ Recife 10, 3-15.

Gough, J. A. \& Murray, N. E. (1983). Sequence diversity among related genes for recognition of specific targets in DNA molecules. J Mol Biol 166, 1-19.

Henikoff, S. (1984). Unidirectional digestion with exonuclease III creates targeted breakpoints for DNA sequencing. Gene 28, 351-359.

Hermans, M. A. F., Neuss, B. \& Sahm, H. (1991). Content and composition of hopanoids in Zymomonas mobilis under various growth conditions. J Bacteriol 173, 5592-5595.

Horbach, S., Neuss, B. \& Sahm, H. (1991). Effect of azasqualene on hopanoid biosynthesis and ethanol tolerance of Zymomonas mobilis. FEMS Microbiol Lett 79, 347-350.

Ingram, L. O. (1986). Microbial tolerance to alcohols: role of the cell membrane. Trends Biotechnol 4, 40-44.

Kessler, C., Höltke, H. J., Seibl, R., Burg, J. \& Mühlegger, K. (1990). Non-radioactive labeling and detection of nucleic acids. Biol Chem Hoppe-Seyler 371, 917-927.

Low, B. (1968). Formation of merodiploids with a class of $\mathrm{rec}^{-}$ recipient strains of Escherichia coli K12. Proc Natl Acad Sci USA 60, $160-167$.

Mullis, K. B. \& Faloona, F. A. (1987). Specific synthesis of DNA in vitro via a polymerase-catalyzed chain reaction. Methods Enzymol 155, 335-350.

Neumann, S. \& Simon, H. (1986). Purification, partial charac- 
terization and substrate specificity of a squalene cyclase from Bacillus acidocaldarius. Biol Chem Hoppe-Seyler 367, 723-729.

Ochs, D., Tappe, C. H., Gärtner, P., Kellner, R. \& Poralla, K. (1990). Properties of purified squalene-hopene cyclase from Bacillus acidocaldarius. Eur J Biochem 194, 75-80.

Ochs, D., Kaletta, C., Entian, K.-D., Beck-Sickinger, A. \& Poralla, K. (1992). Cloning, expression, and sequencing of squalene-hopene cyclase, a key enzyme in triterpenoid metabolism. J Bacteriol 174, 298-302.

Ourisson, G., Albrecht, P. \& Rohmer, M. (1984). The microbial origin of fossil fuels. Sci Am 245, 34-41.

Poralla, K. \& Kannenberg, E. (1987). Hopanoids : sterol equivalents in bacteria. Am Chem Soc Symp Ser 325, 239-251.

Poralla, K., Hewelt, A., Prestwich, G. D., Abe, I., Reipen, I. \& Sprenger, G. A. (1994). A specific amino acid repeat in squalene and oxidosqualene cyclases. Trends Biochem Sci 19, 157-158.

Queen, C. \& Korn, L. J. (1984). A comprehensive sequence analysis program for the IBM personal computer. Nucleic Acids Res 12, 581-599.

Roessner, C. A., Min, C., Hardin, S. H., Harris-Haller, L. W., McCollum, J. C. \& Scott, A. I. (1993). Sequence of the Candida albicans erg7 gene. Gene 127, 149-150.

Rohmer, M., Anding, C. \& Ourisson, G. (1980). Non-specific biosynthesis of hopane triterpenes by a cell-free system from Acetobacter pasteurianum. Eur J Biochem 112, 541-547.

Sahm, H., Rohmer, M., Bringer-Meyer, S., Sprenger, G. A. \& Welle, R. (1993). Biochemistry and physiology of hopanoids in bacteria. Adv Microb Physiol 35, 247-273.

Sambrook, J., Fritsch, E. F. \& Maniatis, T. (1989). Molecular Cloning: a Laboratory Manual, 2nd edn. Cold Spring Harbor, NY: Cold Spring Harbor Laboratory.

Sanger, F., Nicklen, S. \& Coulson, A. R. (1977). DNA sequencing with chain-terminating inhibitors. Proc Natl Acad Sci USA 74, 5463-5467.

Schulenberg-Schell, H., Neuss, B. \& Sahm, H. (1989). Quantitative determination of various hopanoids in microorganisms. Anal Biochem 181, 120-124.

Seckler, B. \& Poralla, K. (1986). Characterization and partial purification of squalene-hopene-cyclase from Bacillus acidocaldarius. Biochim Biophys Acta 881, 356-363.

Southern, E. M. (1975). Detection of specific sequences among DNA fragments separated by gel electrophoresis. J Mol Biol 98, 503-517.

Tabor, S. \& Richardson, C. C. (1987). DNA sequence analysis with a modified bacteriophage T7 polymerase. Proc Natl Acad Sci US A 84, 4767-4771.

Tappe, C. H. (1993). Squalen-Hopen-Cyclasen: Reinigung, Charakterisierung und Inhibitor-Experimente. $\mathrm{PhD}$ thesis, University of Tübingen, Germany.

Taylor, R. F. (1984). Bacterial triterpenoids. Microbiol Rev 48, 181-198.

Tinoco, I., Borer, P. N., Dengeler, B., Levine, M. J., Uhlenbeck, C. O., Crothers, D. M. \& Gralla, J. (1973). Improved estimation of secondary structure in ribonucleic acids. Nature New Biol 246, $40-41$.

Uhlenbusch, I., Sahm, H. \& Sprenger, G. A. (1991). Expression of an $\mathrm{L}$-alanine dehydrogenase gene in Zymomonas mobilis and excretion of L-alanine. Appl Environ Microbiol 57, 1360-1366.

Vieira, J. \& Messing, J. (1982). The pUC plasmids, an M13 mp7derived system for insertion mutagenesis and sequencing with synthetic universal primers. Gene 19, 259-268.

Received 9 May 1994; revised 16 August 1994; accepted 5 September 1994. 